BIORHEOLOGY Vol. 16, pp. 373-374

Pergamon Press Ltd. 1979. Printed in Great Britain

\title{
ANNOUNCEMENT
}

THE FOURTH INTERNATIONAL CONGRESS OF BIORHEOLOGY

July 27 - August 1, 1981 Tokyo, Japan

JUNTENDO UNIVERSITY SCHOOL OF MEDICINE, TOKYO

The first circular of the Congress contains the following:

THE INTERNATIONAL SOCIETY OF BIORHEOLOGY

An Affiliated Commission of the International Union for Pure and Applied Biophysics

Council

E. Fukada (Japan) President

A. Silberberg (Israel) Past President and Liaison Representative to International Union of Pure and Applied Biophysics (IUPAB)

T. Azuma (Japan) Vice President

Y.C.B. Fung (USA) Vice President

H.H. Hartert (F.R. Germany) Vice President

V.I. Vorob'ev (USSR) Vice President

D.E. Brooks (Canada) Secretary General

S. Witte (F.R. Germany) Treasurer

H.L. Goldsmith (Canada)

M. Joly (France)

M. Litt (USA)

H. Schmid-Schönbein (F.R. Germany)

A.L. Copley (USA) Chairman, Committee on Nomenclature and Liaison Representative to Pergamon Press concerning "Biorheology"

G.V.F. Seaman (USA) Editor of Newsletter of Society

ORGANIZING COMMITTEE OF THE FOURTH INTERNATIONAL CONGRESS

Honorary Committee

Setsuro Ebashi

Noburô Kamiya

Bun-ichi Tamamushi

Organizing Committee

Honorary Chairman: Syoten Oka

Chairman: Eiichi Fukada

Finance: Tetsu Watanuki

Scientific Program: Takehiko Azuma

Social Program: Yoshiaki Inagaki

Secretary General: Yaso'o Matunobu

Treasurer: Mitutosi Kawaguti.

Technical Exhibition: Yukihide Isogai

Local Arrangement: Kazuo Kitamura 


\section{SCIENTIFIC PROGRAM}

The scientific program will include all aspects of deformation and flow in biological systems.

1. blood (plasma, cellular elements, coagulation etc)

2. blood vessel and blood flow

3. biofluids (mucus, synovial fluid, sputum etc)

4. biosolids (bone, cartilage, joint, tooth etc)

5. muscle, lung, skin and other organs and tissues

6. biopolymers

7. membrane and interface

8. cellular and subcellular rheology

9. experimental methods

10. theories

11. clinical biorheology

12. miscellaneous

\section{LANGUAGE}

The official language of the Congress is English. No arrangements will be made for simultaneous interpretation.

\section{SOCIAI, PROGRAM}

Social events will be arranged during the Congress.

\section{CORRESPONDENCE}

Al1 correspondence concerning the Congress should be sent to:

Professor Yaso'o Matunobu, Secretary General

The Fourth International Congress of Biorheology

Department of Physics, Keio University,

Hiyoshi, Kohoku-ku, Yokohama 223

JAPAN

\section{TRAVEL ARRANGEMENT}

Group flights will be planned from Europe and USA. Japan Air Lines and Hankyu Express International have been appointed as the official carrier and travel agency for the Congress.

The second circular will be sent to all who return the application form. This circular will contain further information on the scientific and social program, hotel accommodation, a final registration form, and other pertinent information.

Application Forms can be obtained in writing to whose address is given above. 